\title{
Diversity and seasonality of fruit flies (Diptera: Tephritidae and Lonchaeidae) and their parasitoids (Hymenoptera: Braconidae and Figitidae) in orchards of guava, loquat and peach
}

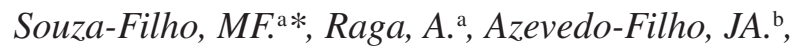 \\ Strikis, PC. ${ }^{\mathrm{c}}$, Guimarães, JA. ${ }^{\mathrm{d}}$ and Zucchi, RA. ${ }^{\mathrm{e}}$ \\ ${ }^{\mathrm{a}}$ Instituto Biológico, \\ Rod. Heitor Penteado, Km 3, Brandina, CEP 13092-543, Campinas, SP, Brazil \\ 'Pólo Regional do Leste Paulista, Agência Paulista de Tecnologia dos Agronegócios - APTA, \\ Estrada Nelson Taufic Nassif, Km 3, Lambedor, CP 1, CEP 13910-000, Monte Alegre do Sul, SP, Brazil \\ 'Departamento de Parasitologia, Instituto de Biologia, \\ Universidade Estadual de Campinas - UNICAMP, \\ Rua Monteiro Lobato, 255, CEP 13083-862, Campinas, SP, Brazil \\ ${ }^{\mathrm{d}}$ Embrapa Agroindústria Tropical, \\ Rua Dra. Sara Mesquita, 2270, Planalto do Pici, CP 3761, CEP 60511-110, Fortaleza, CE, Brazil

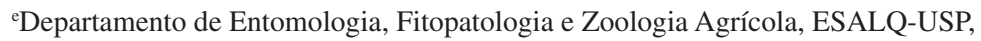 \\ Av. Pádua Dias, 11, Agronomia, CP 9, CEP 13418-900, Piracicaba, SP, Brazil \\ *e-mail: miguelf@biologico.sp.gov.br
}

Received April 10, 2007 - Accepted June 29, 2007 - Distributed February 38, 2009

(With 3 figures)

\begin{abstract}
This work was carried out in orchards of guava progenies, and loquat and peach cultivars, in Monte Alegre do Sul, SP, Brazil, in 2002 and 2003. Guavas and loquats were bagged and unbagged bi-weekly and weekly, respectively, for assessment of the infestation period. Peach was only bagged weekly. The assays started when the fruits were at the beginning of development, but still green. Ripe fruits were taken to the laboratory and placed individually into plastic cups. McPhail plastic traps containing torula yeast were hung from January 2002 to January 2004 to assess the fruit fly population in each orchard, but only the Ceratitis capitata population is here discussed. Five tephritid species were reared from the fruits: Anastrepha bistrigata Bezzi, A. fraterculus (Wiedemann), A. obliqua (Macquart), A. sororcula Zucchi, and C. capitata, in addition to six lonchaeid species: Neosilba certa (Walker), N. glaberrima (Wiedemann), N. pendula (Bezzi), N. zadolicha McAlpine and Steyskal, Neosilba sp. 4, and Neosilba sp. 10 (both species are in the process of being described by P. C. Strikis), as well as some unidentified Neosilba species. Ten parasitoid species were obtained from fruit fly puparia, of which five were braconids: Asobara anastrephae (Muesebeck), Doryctobracon areolatus (Szépligeti), D. brasiliensis (Szépligeti), Opius bellus Gahan, and Utetes anastrephae (Viereck), and five figitids: Aganaspis pelleranoi (Brèthes), Dicerataspis grenadensis Ashmead, Lopheucoila anastrephae (Rhower), Leptopilina boulardi (Barbotin, Carlton and Kelner-Pillaut), and Trybliographa infuscata Diaz, Gallardo and Uchôa. Ceratitis capitata showed a seasonal behavior with population density peaking at the second semester of each year. Anastrepha and Neosilba species remained in the orchards throughout both years.
\end{abstract}

Keywords: Anastrepha, Ceratitis capitata, Neosilba, host succession, biological control.

\section{Diversidade e variação sazonal de moscas-das-frutas \\ (Diptera: Tephritidae, Lonchaeidae) e seus parasitóides \\ (Hymenoptera: Braconidae, Figitidae) em pomares de goiaba, nêspera e pêssego}

\section{Resumo}

Este trabalho foi realizado em três pomares em Monte Alegre do Sul, SP, em 2002 e 2003, representados por coleção de progênies de goiabeiras, de cultivares de nespereiras e de cultivares de pessegueiros. O período de infestação foi determinado por meio de ensacamento e desensacamento quinzenal e semanal de goiabas e nêsperas, respectivamente, e pelo ensacamento semanal de pêssegos. Os ensaios iniciaram-se com os frutos verdes (princípio de desenvolvimento). Os frutos maduros foram levados ao laboratório e acondicionados individualmente em copos plásticos. A flutuação populacional de Ceratitis capitata (Wiedemann) foi avaliada por meio de armadilhas plásticas modelo McPhail 
com torula em cada pomar, de janeiro/2002 a janeiro/2004. Dos frutos foram obtidas cinco espécies de tefritídeos: Anastrepha bistrigata Bezzi, A. fraterculus (Wiedemann), A. obliqua (Macquart), A. sororcula Zucchi e C. capitata e seis de lonqueídeos: Neosilba certa (Walker), N. glaberrima (Wiedemann), N. pendula (Bezzi), N. zadolicha McAlpine and Steyskal, Neosilba sp. 4 e Neosilba sp. 10, além de algumas espécies não-identificadas. Foram obtidas 10 espécies de parasitóides, cinco da família Braconidae - Asobara anastrephae (Muesebeck), Doryctobracon areolatus (Szépligeti), D. brasiliensis (Szépligeti), Opius bellus Gahan e Utetes anastrephae (Viereck) - e cinco da família Figitidae - Aganaspis pelleranoi (Brèthes), Dicerataspis grenadensis Ashmead, Lopheucoila anastrephae (Rhower), Leptopilina boulardi (Barbotin, Carlton and Kelner-Pillaut) e Trybliographa infuscata Diaz, Gallardo and Uchôa. Ceratitis capitata apresentou comportamento sazonal com picos populacionais durante o segundo semestre dos dois anos. As espécies de Anastrepha e de Neosilba permaneceram nos pomares durante os dois anos.

Palavras-chave: Anastrepha, Ceratitis capitata, Neosilba, sucessão de hospedeiros, controle biológico.

\section{Introduction}

Plant susceptibility to insects depends on the phenological synchrony between both. In turn, a suitable plant for the development of an insect population can often escape herbivory because the insect seasonality does not coincide with the plant susceptible stage (Messina and Jones, 1990).

Knowledge about fruit fly species and their respective seasonalities related to host plant phenology is crucial to understand the population dynamics of these insects. Fruit infestation is influenced by its degree of maturation during the fruit fly oviposition period (Messina and Jones, 1990). Foraging differences can be observed, as fruit flies make incursions into fruits of a certain developmental stage. Such information can be obtained by bagging and unbagging fruits throughout their development (Dias and Vásquez, 1993).

Tephritidae and Lonchaeidae representatives present a broad array of fly species whose larvae use the pulp of fruits or even other plant tissues as substrate for their development. However, because tephritids have a higher number of species of economic importance, they are more frequently studied worldwide (Aluja and Norrbom, 2000).

In Brazil, the fruit fly species of economic importance consist basically of some Anastrepha species and Ceratitis capitata (Wiedemann). In addition to these tephritids, some lonchaeid species have also been considered primary pests in Brazil (Lourenção et al., 1996; Araujo and Zucchi, 2002; Souza-Filho et al., 2002; Uchôa-Fernandes et al., 2003; Aguiar-Menezes et al., 2004; Raga et al., 2004; Souza et al., 2005).

Fruit flies are considered key pests in guava (Gould and Raga, 2002). Ten species are associated with guava in Brazil - A. antunesi Costa Lima, A. bahiensis Costa Lima, A. bistrigata Bezzi, A. fraterculus (Wiedemann), A. leptozona Hendel, A. obliqua (Macquart), A. sororcula Zucchi, A. striata Schiner, A. turpiniae Stone, and A. zenildae Zucchi, in addition to $C$. capitata (Malavasi et al., 1980; Souza-Filho, 1999; Araujo and Zucchi, 2003). Five fruit fly species are associated with loquat in Brazil A. fraterculus, A. obliqua, A. sororcula, A. turpiniae, and C. capitata (Salles, 1995; Aguiar-Menezes and Menezes, 1996; Souza-Filho, 1999). The fruit flies associated with peach in Brazil belong to four species - A. fraterculus,
A. sororcula, A. turpiniae and C. capitata (Malavasi et al., 1980; Veloso, 1997; Souza-Filho, 1999). Considering these hosts, Anastrepha fraterculus is more important in the states of Rio Grande do Sul, Santa Catarina, and Paraná (Salles, 1998), while C. capitata is more important in the State of São Paulo (Souza-Filho, 1999).

The objective of this study was to verify whether fruit flies present seasonality in three contiguous orchards, relating these data to host phenology and to parasitoids.

\section{Material and Methods}

The study was conducted at the experiment station of the Pólo Regional de Desenvolvimento Tecnológico dos Agronegócios do Leste Paulista/Agência Paulista de Tecnologia dos Agronegócios (PRDTALP/APTA), during 2002 and 2003, in Monte Alegre do Sul, SP ( $22^{\circ} 40^{\prime} 50^{\prime \prime} \mathrm{S}$ and $46^{\circ} 40^{\prime} 45^{\prime \prime} \mathrm{W}$; $760 \mathrm{~m}$ ). The experiments were carried out in three orchards: a collection of guava progenies (Psidium guajava L.); a collection of loquat cultivars [Eriobotrya japonica (Thunb.) Lindl.]; and a collection of peach [Prunus persica (L.) Batsch] and nectarine ( $P$. persica var. nucipersica) cultivars. No phytosanitary treatments were performed in the orchards during the assays.

\subsection{Fruit fly infestation period determination}

In each assay, we used three guava progenies (Guanabara, $\mathrm{L}_{7} \mathrm{P}_{28}$, and 252), two loquat cultivars (Campinas Early and 264-54 Early), and three peach cultivars (Aurora 2, Dourado 1, and Régis), as a measure of plant uniformity. These progenies and cultivars will be referred to by their respective common names throughout the text.

Guava: The first assay began on 11/01/2002, when the fruits of progenies Guanabara and $\mathrm{L}_{7} \mathrm{P}_{28}$ showed mean diameters of 2.8 and $2.3 \mathrm{~cm}$, respectively. The second assay began on $27 / 12 / 2002$, when the fruits of progenies Guanabara and 252 showed mean diameters of 2.4 and $2.3 \mathrm{~cm}$, respectively. A total of 500 guavas of each progeny were protected with small wax-coated, pleated paper bags $(19.5 \times 11 \mathrm{~cm})$. Such large amount of bagged fruits was used to ensure the unbagging of ripe fruits. Every other week, 30 guavas (60 per evaluation) were bagged 
and unbagged, and tied with color-coded strings to allow the identification of each activity by date. In addition to these identified fruits, another 30 fruits of each progeny were selected, remaining completely free from bagging, as well as 30 fruits of each progeny which remained bagged since the beginning of each assay. The number of studied fruits was not equal to the total number of marked fruits, due to losses to diseases or premature shedding. The fruits were taken to the laboratory and placed individually in $500 \mathrm{~mL}$ capacity plastic pots containing sand + vermiculite covered with voile fabric held in place with elastic tape. Each fruit remained in the plastic pot for approximately 20 days until the emergence of flies and/ or parasitoids. The emerged insects were counted, sexed (flies only) and maintained in properly labeled vials containing $70 \%$ alcohol, for subsequent identification.

Loquat: The assay began on 29/07/2002, when the fruits of cultivars IAC-Campinas Early and 264-54 Early showed mean diameters of 1.2 and $1.1 \mathrm{~cm}$, respectively. The 2003 assay began on 29/07, when fruits of the Campinas Early cultivar showed a mean diameter of $2 \mathrm{~cm}$. Four hundred and 300 loquats were bagged and unbagged weekly in 2002 and 2003, respectively. Thinning was done during bagging, leaving 3 to 6 fruits in each bunch. All other procedures were identical to the guava assays; however, $250 \mathrm{~mL}$ capacity plastic pots were used.

Peach: The assay began on $19 / 08 / 2002$, when the cultivars Aurora 2 and Dourado 1 peaches showed mean diameters of 2 and $2.1 \mathrm{~cm}$, respectively. In 2003, the assay began on $12 / 08$, when the cultivar Régis fruits showed a mean diameter of $1.9 \mathrm{~cm}$. Bagging was only performed weekly, in view of the reduced number of plants per cultivar and low production of fruits. The other procedures were identical to those carried out for guavas, except for the quantity of selected fruits, i.e., 30 fruits were kept without bagging.

\subsection{Identification of fruit fly and parasitoid species}

The term "fruit fly" is herein employed both for Tephritidae and Lonchaeidae specimens, whose larvae are frugivorous as well. Fly identifications were based on Zucchi (2000) for Anastrepha species and on McAlpine and Steyskal (1982) for Neosilba species. As fraterculus complex is formed by several cryptic species (Hernández-Ortiz et al., 2004; Selivon et al., 2005), the name $A$. fraterculus is being used herein in its sensu lato. Parasitoid identifications were based on Canal and Zucchi (2000) for braconids and on Guimarães et al. (2000, 2003) for figitids. Voucher specimens were deposited in the collection of the Instituto Biológico. Ceratitis capitata is the unique species of the genus reported in Brazil.

\subsection{C. capitata population fluctuation}

Three McPhail-type plastic traps containing torula yeast were hung in each orchard, from 04/01/2002 to 16/01/2004 and they were checked weekly. Tephritids and lonchaeids were separated, counted in the labora- tory, and transferred to labeled glass vials containing $70 \%$ alcohol, for identification. Anastrepha species were not identified because of the huge number of specimens collected (more than 90 thousand). Ceratitis capitata population levels in each orchard were estimated based on the number of individuals captured weekly (males and females), transformed to number of flies captured/ trap/day (FTD).

\section{Results and Discussion}

\subsection{Fruit flies}

The diversity of flies in guava, loquat, and peach in Monte Alegre do Sul, SP in 2002 and 2003 consisted of Tephritidae and Lonchaeidae representatives (11 species and four genera) (Table 1).

Five species of Tephritidae were collected: A. bistrigata Bezzi, A. fraterculus (Wiedemann), A. obliqua (Macquart), A. sororcula Zucchi, and Ceratitis capitata (Wiedemann). Anastrepha species occurred in guava in 2002 and 2003, but $C$. capitata was not reared from this host. Only A. fraterculus and $C$. capitata occurred in loquat, in both years of studies. In peach, A. fraterculus and $C$. capitata infestations also occurred in 2002. In 2003, besides these two species, A. obliqua also occurred (Table 1). Anastrepha fraterculus and C. capitata are extremely generalist with regard to host exploitation and are the species with the greatest economic importance in Brazil (e.g. Zucchi, 2000).

Guava presented the greatest tephritid species diversity, confirming its condition of host with the highest number of fruit fly species in Brazil (Malavasi et al., 1980; Silva et al., 1996; Veloso, 1997; Souza-Filho, 1999). Anastrepha bistrigata is commonly associated with Myrtaceae in the genus Psidium, while A. sororcula, although generalist, infests preferentially Myrtaceae fruits (Norrbom and Kim, 1988).

Among lonchaeids, Neosilba species were the most numerous. Four species were identified: $N$. certa (Walker), N. glaberrima (Wiedemann), N. pendula (Bezzi), N. zadolicha McAlpine and Steyskal, besides two species still being described - Neosilba sp. 4 and Neosilba sp. 10 and other unidentified species (Neosilba spp.). Only $N$. certa occurred in the three hosts in both years of study. Neosilba sp. 4 and Neosilba sp. 10 only occurred in peach and guava, respectively. Occurrence of the other species varied with regard to the exploitation of fruits in both years; nevertheless, polyphagy was also observed (Table 1).

Recently Souza et al. (2005) reported N. certa, N. glaberrima, N. pendula, and Neosilba sp. 10 infesting arabica coffee in Valença, RJ. So, probably the coffee growing areas around the three orchards are important as repositories for lonchaeid host succession. Neosilba pendula is a primary acerola invader in the Mossoró, RN region; but it is a polyphagous species as it infests another seven species of fruits, including guava (Araujo and 
Table 1. Seasonal variation in fly (Tephritidae and Lonchaeidae) and parasitoid diversity (Braconidae and Figitidae) in guava, loquat, and peach in Monte Alegre do Sul, SP, 2002-2003.

\begin{tabular}{|c|c|c|c|c|c|c|}
\hline \multirow[t]{3}{*}{ Fruit flies } & \multicolumn{3}{|c|}{2002} & \multicolumn{3}{|c|}{2003} \\
\hline & Feb.-Apr. & Sept. & Sept.-Oct. & Feb. - Apr. & Aug.-Sept. & Sep.-Nov. \\
\hline & Guava & Loquat & Peach & Guava & Loquat & Peach \\
\hline \multicolumn{7}{|l|}{ TEPHRITIDAE } \\
\hline A. bistrigata & $\checkmark$ & - & - & $\checkmark$ & - & - \\
\hline A. fraterculus & $\checkmark$ & $\checkmark$ & $\checkmark$ & $\checkmark$ & $\checkmark$ & $\checkmark$ \\
\hline A. obliqua & $\checkmark$ & - & - & $\checkmark$ & - & $\checkmark$ \\
\hline A. sororcula & $\checkmark$ & - & - & $\checkmark$ & - & - \\
\hline C. capitata & - & $\checkmark$ & $\checkmark$ & - & $\checkmark$ & $\checkmark$ \\
\hline \multicolumn{7}{|l|}{ LONCHAEIDAE } \\
\hline Neosilba spp. & $\checkmark$ & $\checkmark$ & $\checkmark$ & $\checkmark$ & $\checkmark$ & $\checkmark$ \\
\hline$N$. certa & $\checkmark$ & $\checkmark$ & $\checkmark$ & $\checkmark$ & $\checkmark$ & $\checkmark$ \\
\hline N. glaberrima & $\checkmark$ & - & - & $\checkmark$ & - & $\checkmark$ \\
\hline N. pendula & $\checkmark$ & - & $\checkmark$ & $\checkmark$ & $\checkmark$ & $\checkmark$ \\
\hline N. zadolicha & $\checkmark$ & $\checkmark$ & $\checkmark$ & $\checkmark$ & - & $\checkmark$ \\
\hline Neosilba sp. 4 & - & - & $\checkmark$ & - & - & $\checkmark$ \\
\hline Neosilba sp. 10 & $\checkmark$ & - & - & - & - & - \\
\hline Lonchaea spp. & $\checkmark$ & - & - & - & - & $\checkmark$ \\
\hline Parasitoids & Guava & Loquat & Peach & Guava & Loquat & Peach \\
\hline \multicolumn{7}{|l|}{ BRACONIDAE } \\
\hline A. anastrephae & - & - & - & $\checkmark$ & - & - \\
\hline D. areolatus & $\checkmark$ & - & $\checkmark$ & $\checkmark$ & - & $\checkmark$ \\
\hline D. brasiliensis & $\checkmark$ & - & $\checkmark$ & $\checkmark$ & - & $\checkmark$ \\
\hline Opius bellus & - & - & $\checkmark$ & - & - & - \\
\hline U. anastrephae & - & - & $\checkmark$ & - & - & - \\
\hline \multicolumn{7}{|l|}{ FIGITIDAE } \\
\hline A. pelleranoi & - & - & - & $\checkmark$ & - & - \\
\hline D. grenadensis ${ }^{1}$ & - & - & - & $\checkmark$ & - & - \\
\hline L. anastrephae & $\checkmark$ & - & - & $\checkmark$ & - & - \\
\hline L. boulardi ${ }^{1}$ & - & - & - & $\checkmark$ & - & - \\
\hline T. infuscata & - & - & - & $\checkmark$ & - & - \\
\hline
\end{tabular}

${ }^{1}$ Parasitoids associated with Drosophilidae.

Zucchi, 2002). Neosilba zadolicha is also polyphagous and has a great niche exploitation capacity, as it has been observed attacking Spondias sp. fruits (Anacardiaceae) and passion fruit vine flower buds and fruits (UchôaFernandes et al., 2002; Aguiar-Menezes et al., 2004; Santos et al., 2004).

The genus Lonchaea Fallén was represented by a reduced number of unidentified specimens, obtained from guava and peach (Table 1). On the latter host, a record exists for L. chalybea Wiedemann and for another unidentified species in the State of Paraná (Fehn, 1981).

\subsection{Relation between tephritids $\times$ hosts}

Due to the proximity between the guava, loquat, and peach orchards, we could establish the distribution of fruit fly species in shared fruits with time, by means of fruit bagging (Figures 1 and 2). Loquat has two fruiting periods per year; however, the infestation studies were conducted in the second fruiting period, in the second semester of 2002 and 2003.

Anastrepha fraterculus in guava showed a population increase tendency in March, when full fruits were completely ripe, and another tendency of increase starting in August and continuing until September, comprising the loquat and peach fruiting periods (Figures 1 and 2). In another county of the State of São Paulo, A. fraterculus adult population peak occurred only in the end of the host fruit season (Malavasi and Morgante, 1981). In the State of Rio de Janeiro, A. fraterculus also has two population peaks, from March to April and from September (Aguiar-Menezes and Menezes, 1996). According to all these data, A. fraterculus population peaks is influenced by the host fruiting periods.

The population of A. obliqua occurred at the guava fruiting season (March) and again in September, coming 

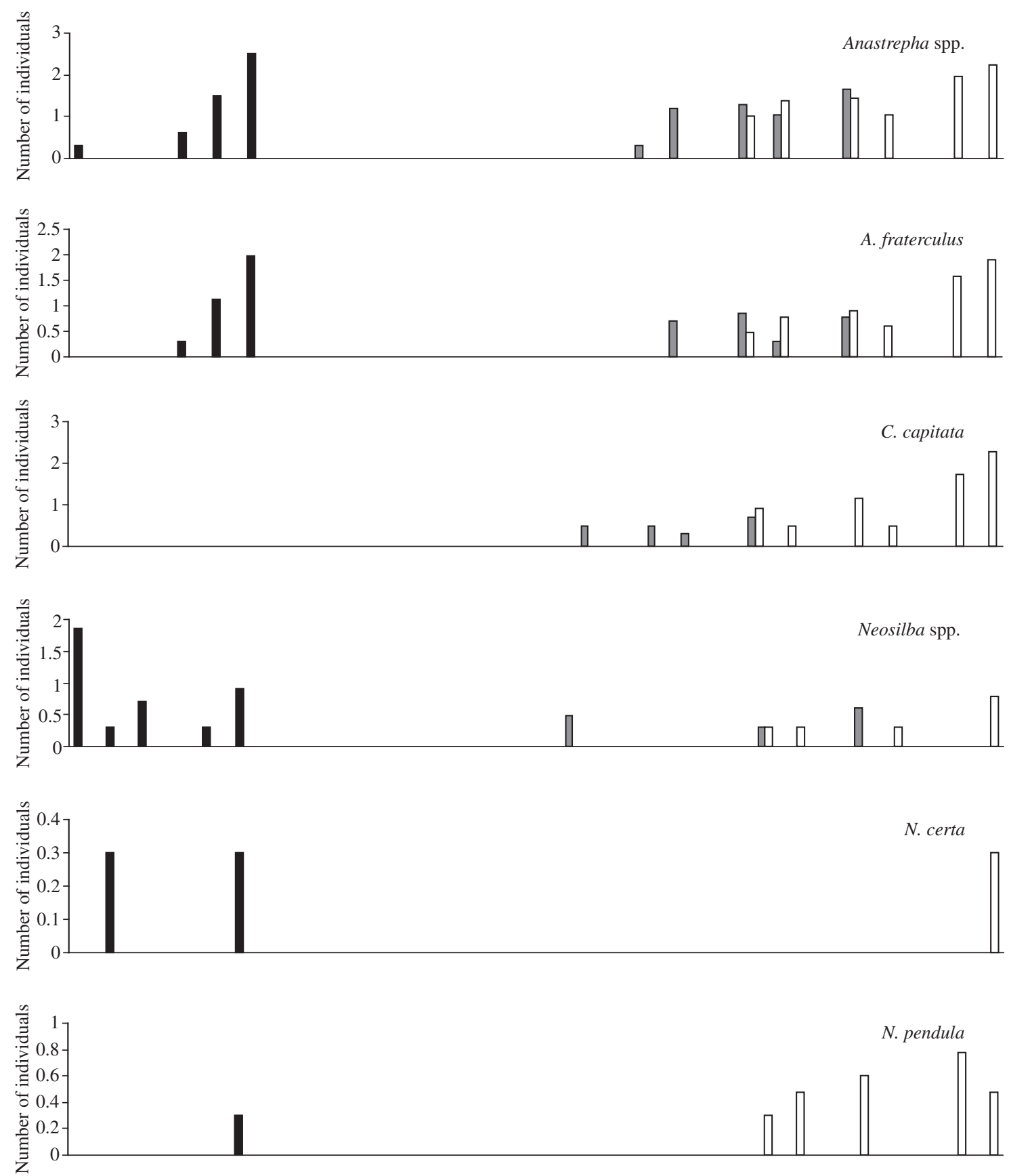

Guava $\square$ Loquat $\square$ Peach

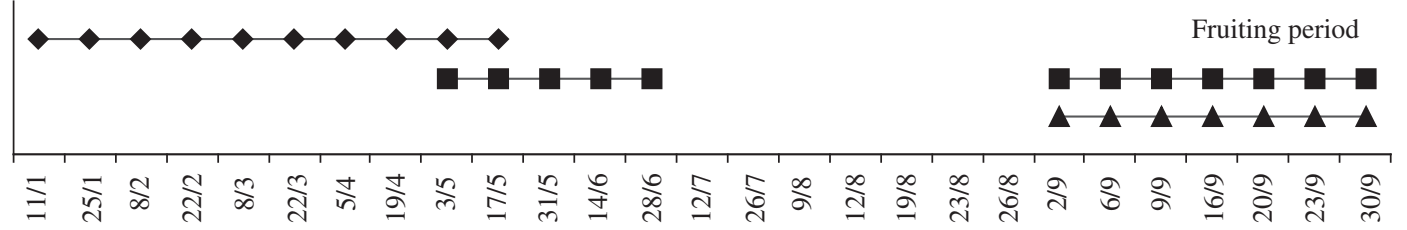

Figure 1. Fly seasonality in guava (lozenge), loquat (square), and peach (triangle), related to the period of exposure of fruits after bagging, in Monte Alegre do Sul, SP, 2002. Fly numbers were transformed to $\log _{10}(n+1)$. 

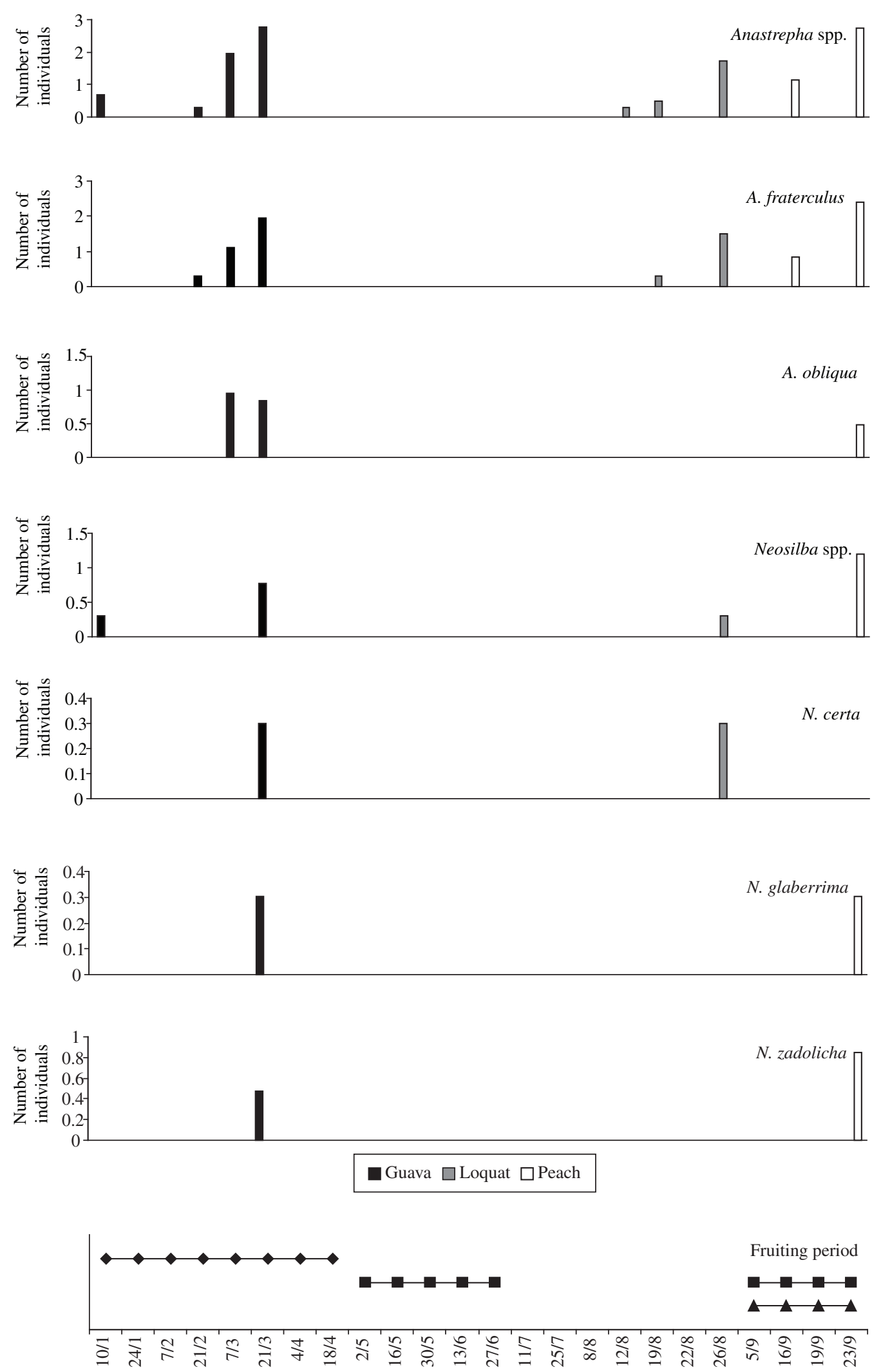

Figure 2. Fly seasonality in guava (lozenge), loquat (square), and peach (triangle), related to the period of exposure of fruits after bagging, in Monte Alegre do Sul, SP, 2003. Fly numbers were transformed to $\log _{10}(n+1)$. 
from peaches of the 2003 cropping season (Figure 2). Although it was not obtained from loquat in both fruiting seasons of the year, A. obliqua had already been reported on this host in the State of São Paulo (Souza-Filho et al., 2000). It is likely that host availability throughout the year may have helped to maintain this species in the area where the orchards were located. Considering that around Monte Alegre do Sul, SP there are cultivated and spontaneous mango plants (Mangifera indica L.), probably this fruit tree contributed toward A. obliqua host succession.

Ceratitis capitata infested loquat and peach in August and September 2002, when there was a tendency of population increase (Figure 1). The fluctuation data reinforce this evidence, with population peaks in September, in the full fruiting period of these Rosaceae (Figure 3). The Mediterranean fruit fly was practically absent from January to July in the three orchards, and a single population peak occurred in each year (Figure 3 ). Therefore, the $C$. capitata population has a defined seasonality, since even in loquat trees, which have two fruiting seasons per year, the number of specimens collected in the first fruiting period (May through July) was minimal (Figure 3). On the other hand, the population peaks of $C$. capitata in loquat and peach occurred during the fruiting season observed in the second half of the year (September and October) (Figure 3). Consequently there was an incursion of $C$. capitata into these orchards, as exemplified in observations of Israely et al. (1997). The C. capitata population parameters are substantially influenced by the hosts, which act mainly as breeding and refuge substrates (Katsoyannos et al., 1998). These authors also considered that breeding within the population activity period (abundance) seems to be closely associated with the seasonal maturation of the most important host in the area. Ceratitis capitata seasonality also became evident in the guava orchard from the end of February to the end of April, when no flies were captured even at full fruiting (Figure 3). Considering the C. capitata preference for coffee and peach (Souza-Filho, 1999), it is possible to infer that the seasonality in this study resulted from the coffee harvest in the surroundings of Monte Alegre do Sul. Other population fluctuation studies in the State of São Paulo have also demonstrated this tendency (e.g. Puzzi and Orlando, 1965). Even in tropical regions, C. capitata occurs more frequently on introduced hosts (Malavasi et al., 1980). The population peak in the guava orchard in the period without fruits, vegetative stage, and beginning of flowering (Figure 3 ) demonstrates that the C. capitata population exploited the site to obtain food and shelter (Hendrichs and Hendrichs, 1990).

\subsection{Relation between lonchaeids $\mathrm{x}$ hosts}

In general, the Neosilba species occurred in the orchards throughout the two years of studies (Figures 1 and 2). Neosilba certa, Neosilba sp. 4, and Neosilba sp. 10 occurred in both years and exploited the three hosts. In 2002, N. pendula exploited guava and peach, while in 2003
$N$. glaberrima and $N$. zadolicha also occurred in guava and peach. These species use a commercial guava orchard as copulation site (Strikis and Souza-Filho, 2004).

The Neosilba specimens obtained directly from fruits not previously attacked by tephritids confirm that these flies also are primary invaders of fruits. In this work, this fact was observed for $N$. certa and unidentified species (Neosilba spp.) in guava, on two occasions (end of January and beginning of February, 2002) (Figure 1). In Brazil, there are records for $N$. certa and $N$. zadolicha in peach (Fehn, 1981; McAlpine and Steyskal, 1982) and N. pendula in guava (Araujo and Zucchi, 2002). However, Neosilba species are also primary invaders of citrus in Brazil (Uchôa-Fernandes et al., 2002; Raga et al., 2004). The records obtained in this work for $N$. certa and $N$. zadolicha in guava and loquat and for $N$. glaberrima in guava and peach are unprecedented.

\subsection{Parasitoids}

Ten parasitoid species were collected. The braconids belonged to five species - Asobara anastrephae (Muesebeck), Doryctobracon areolatus (Szépligeti), D. brasiliensis (Szépligeti), Opius bellus Gahan, and Utetes anastrephae (Viereck) (Table 1). Doryctobracon areolatus, D. brasiliensis, and $U$. anastrephae can be highlighted as the most important parasitoids in the State of São Paulo, parasitizing fly larvae on practically all known host plants (Souza-Filho et al., 2000).

Figitids were retrieved from larvae attacking only guava - Aganaspis pelleranoi (Brèthes), Dicerataspis grenadensis Ashmead, Lopheucoila anastrephae (Rhower), Leptopilina boulardi (Barbotin, Carlton and Kelner-Pillaut), and Trybliographa infuscata Diaz, Gallardo and Uchôa (Table 1). With the exception of D. grenadensis and L. boulardi, which are parasitoids on drosophilids, the other figitids parasitize Tephritoidea larvae (Guimarães et al., 2004).

At the end of the maturation stage, some fruits harvested from the trees showed cracks or were damaged by insects or birds. These fruits became attractive to drosophilids and, consequently, emergence of $D$. grenadensis and $L$. boulardi was observed, since these parasitoids are more attracted by rotting guava volatiles infested with drosophilid larvae (Guimarães and Zucchi, 2004). Myrtaceae fruits are more attractive to figitids (Guimarães et al., 2004). Thus, only larvae in guava were parasitized.

Most braconid species developed on tephritid larvae in peach in 2002, but only Doryctobracon species D. areolatus and D. brasiliensis - were also obtained in 2003 (Table 1). Larvae in loquat were not parasitized (Table 1). However, there are records of high parasitism rates of larvae in this host (Souza-Filho, 1999).

The parasitoids occurred in periods when the flies are more abundant (Table 1), that is, in the fruiting season of host plants (Figures 1 and 2). In this period, the fruits show characteristics that favor the action of parasitoids, such as increased attractiveness and easier detection of the host larva for oviposition (Ovruski et al., 2000). 
Ripe fruits

Ripe fruits
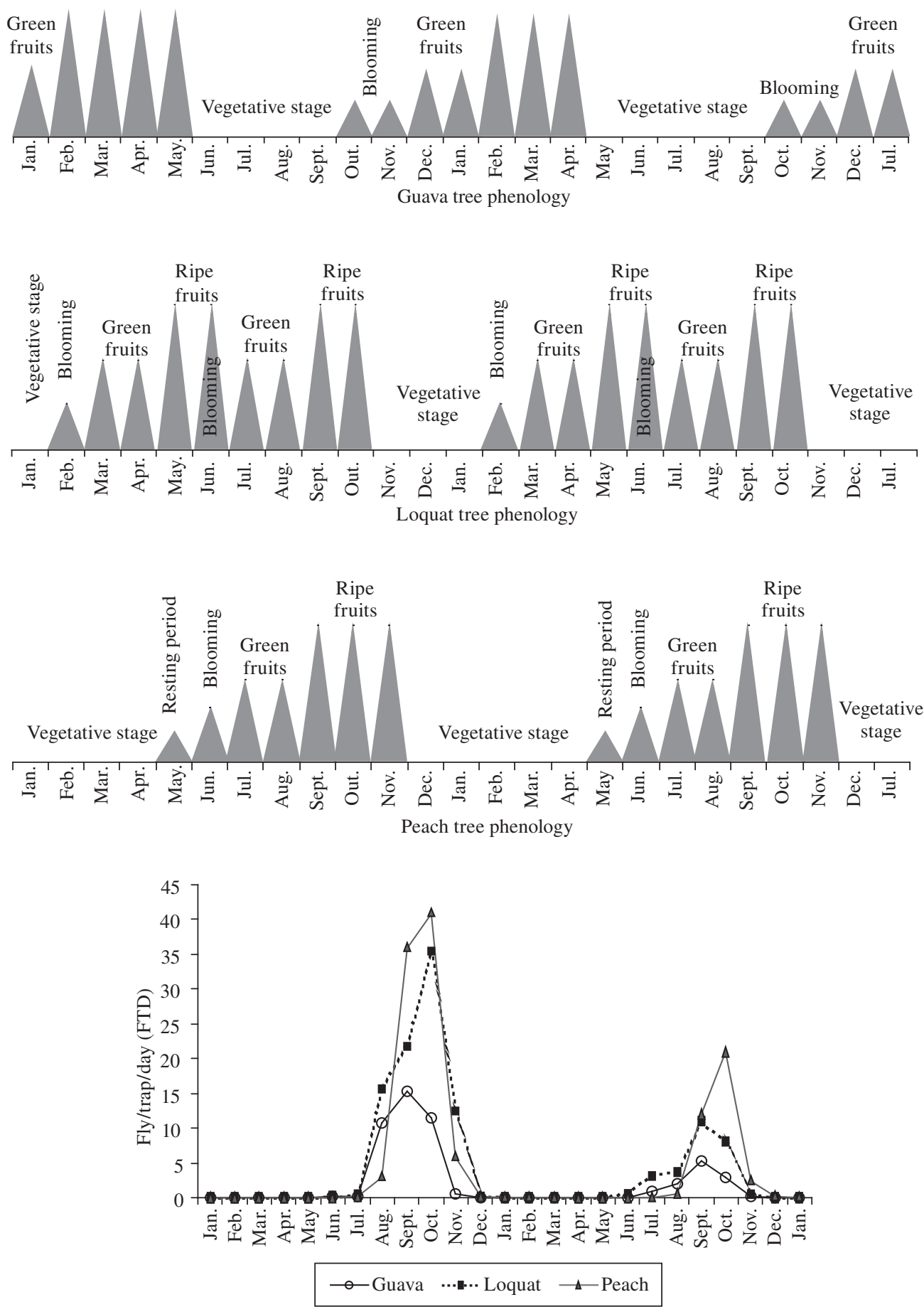

Figure 3. Guava, loquat, and peach tree phenology, and Ceratitis capitata population fluctuation in three orchards from January/2002 to January/2004, in Monte Alegre do Sul, SP, January/2002 to January/2004.

\section{Final Considerations}

Considering the regional approach of this study, it was observed that fly populations, such as Anastrepha fraterculus, A. obliqua, Neosilba certa, N. glaberrima,
$N$. pendula, $N$. zadolicha co-occurred in the three orchards in the two year-round of sampling (exploitation and host succession), while Ceratitis capitata occurred exclusively during the second semester of each year. 
Based on phenological data it was also possible to verify the relative abundance and the population growth dynamics of fruit fly populations during the research period as well as when these populations begin their respective peaks. The parasitoid populations showed great diversity and potential to be used in biological control. This information will be of great importance for the implementation of an integrated pest management of the fruit flies in the studied area.

Acknowledgements - The authors are grateful to Márcio Roberto Ortiz de Souza, Luiz Henrique Chorfi Berton, Anderson Alves Siqueira Pedro and Guilherme de Melo for their collaboration in the field work and laboratory; and to Dr. Thomas Michael Lewinsohn (Universidade Estadual de Campinas/UNICAMP) for his suggestions to improve an earlier version of the manuscript.

\section{References}

AGUIAR-MENEZES, EL. and MENEZES, EB., 1996. Flutuação populacional das moscas-das-frutas e sua relação com a disponibilidade hospedeira em Itaguaí-RJ. An. Soc. Entomol. Bras., vol. 25, no. 2, p. 223-232.

AGUIAR-MENEZES, E, NASCIMENTO, RJ. and MENEZES, EB., 2004. Diversity of fly species (Diptera: Tephritoidea) from Passiflora spp. and their hymenopterous parasitoids in two municipalities of the southeastern Brazil. Neotrop. Entomol., vol. 33 , no. 1, p. 113-116.

ALUJA, M. and NORRBOM,AL., 2000. Fruitflies (Tephritidae): phylogeny and evolution of behavior. Boca Raton: CRC Press. $944 \mathrm{p}$.

ARAUJO, EL. and ZUCCHI, RA., 2002. Hospedeiros e níveis de infestação de Neosilba pendula (Bezzi) (Diptera: Lonchaeidae) na região de Mossoró/Assu, RN. Arq. Inst. Biol., vol. 69, no. 2, p. 91-94.

-, 2003. Moscas-das-frutas (Diptera: Tephritidae) em goiaba (Psidium guajava L.), em Mossoró, RN. Arq. Inst. Biol., vol. 70, no. 1, p. 73-77.

CANAL, NA. and ZUCCHI, RA., 2000. Parasitóides Braconidae. In: Malavasi, A. and ZUCCHI, RA. (Eds.). Moscasdas-frutas de importância econômica no Brasil: conhecimento básico e aplicado. Ribeirão Preto: Holos Editora. 327 p.

DIAZ, FA. and VASQUEZ, RB., 1993. Época de oviposición de la mosca de las frutas (Anastrepha spp.), relacionada con la fenologia de la guayaba nativa. Rev. ICA, vol. 28, no. 4, p. 323-333.

FENH, LM., 1981. Coleta e reconhecimento de moscas das frutas em região metropolitana de Curitiba e Irati, Paraná, Brasil. An. Soc. Entomol. Bras., vol. 10, no. 2, p. 209-238.

GOULD WP. and RAGA, A., 2002. Pest of guava. In PEÑA, JE., SHARP, JL. and WYSOKI, M. (Eds.). Tropical fruit pests and pollinators: biology, economic importance, natural enemies and control. New York: CABI. 448 p.

GUIMARÃES, JA., ZUCCHI, RA., 2004. Parasitism behavior of three species of Eucoilinae (Hymenoptera: Cynipoidea: Figitidae) fruit fly parasitoids (Diptera) in Brazil. Neotrop. Entomol., vol. 33, no. 2, p. 217-224.
GUIMARÃES, JA., DIAZ, NB and ZUCCHI, RA., 2000. Parasitóides - Figitidae (Eucoilinae). In MALAVASI, A. and ZUCCHI, RA. (Eds.). Moscas-das-frutas de importância econômica no Brasil: conhecimento básico e aplicado. Ribeirão Preto: Holos Editora. 327 p.

GUIMARÃES, JA., GALLARDO, FE., DIAZ, NB. and ZUCCHI, RA., 2003. Eucoilinae species (Hymenoptera: Cynipoidea: Figitidae) parasitoids of fruit-infesting dipterous larvae in Brazil: identity, geographical distribution and hosts associations. Zootaxa, no. 278, p. 1-23.

GUIMARÃES, JA., SOUZA-FILHO, MF., RAGA, A. and ZUCCHI, RA., 2004. Levantamento e interações tritróficas de figitídeos (Hymenoptera: Eucoilinae) parasitóides de larvas frugívoras (Diptera) no Brasil. Arq. Inst. Biol., vol. 71, no. 1, p. 51-56.

HENDRICHS, J. and HENDRICHS, MA., 1990. Mediterranean fruit fly (Diptera: Tephritidae) in nature: location and diel pattern of feeding and other activities on fruiting and nonfruiting hosts and nonhosts. Ann. Entomol. Soc. Am., vol. 83, no. 3, p. 632-641.

HERNÁNDEZ-ORTIZ, V., GÓMEZ-ANAYA, JA., SÁNCHEZ, A., McPHERON, BA. and ALUJA, M., 2004. Morphometric analysis of Mexican and South American populations of the Anastrepha fraterculus complex (Diptera: Tephritidae) and recognition of a distinct Mexican morphotype. B. Entomol. Res., vol. 94, no. 6, p. 487-499.

ISRAELY, N., YUVAL, B., KITRON, U. and NESTEL, D., 1997. Population fluctuation of adult mediterranean fruit flies (Diptera: Tephritidae) in mediterranean heterogeneous agricultural region. Environ. Entomol., vol. 26, no. 6, p. 1263-1269.

KATSOYANNOS, BI., KOLOUSSIS, NA. and CAREY, JR., 1998. Seasonal and annual occurrence of mediterranean fruit flies (Diptera: Tephritidae) on Chios Island, Greece: differences between two neighboring citrus orchards. Ann. Entomol. Soc. Am., vol. 91, no. 1, p. 43-51.

LOURENÇÃO, AL., LORENZI, JO. and AMBROSANO, GMB., 1996. Comportamento de clones de mandioca em relação a infestação por Neosilba perezi (Romero \& Ruppell) (Diptera: Lonchaeidae). Sci. Agric. vol. 53, no. 2/3, p. 304-308.

MALAVASI, A. and MORGANTE, JS., 1981. Adult and larval population fluctuation of Anastrepha fraterculus and its relationship to host availability. Environ. Entomol., vol. 10, no. 3 , p. 275-278.

MALAVASI, A., MORGANTE, JS. and ZUCCHI, RA., 1980. Biologia de "moscas-das-frutas" (Diptera: Tephritidae). I. Lista de hospedeiros e ocorrência. Rev. Bras. Biol. = Bras. J. Biol., vol. 40, no. 1, p. 9-16.

McALPINE, JF. and STEYSKAL, G., 1982. A revision of Neosilba McAlpine with a key to the world genera of Lonchaeidae (Diptera). Can. Entomol., vol. 114, no. 2, p. 105-137.

MESSINA, FJ. and JONES, VP., 1990. Relationship between fruit phenology and infestation by the apple maggot (Diptera: Tephritidae) in Utah. Ann. Entomol. Soc. Am., vol. 83, no. 4, p. 742-752.

NORRBOM, AL. and KIM, KC, 1988. A list of the reported host plants of the species of Anastrepha (Diptera: Tephritidae). Washington: USDA, Animal and Plant Health Inspection Service. (APHIS 81-52). $114 \mathrm{p}$. 
OVRUSKI, S., ALUJA, M., SIVINSKI, J. and WHARTON, R., 2000. Hymenopteran parasitoids on fruit-infesting Tephritidae (Diptera) in Latin America and the southern United States: diversity, distribution, taxonomic status and their use in fruit fly biological control. Integr. Pest Manage. Rev., vol. 5, no. 2, p. 81-107.

PUZZI, D. and ORLANDO, A., 1965. Estudos sobre a ecologia das "moscas-das-frutas" (Trypetidae) no Estado de São Paulo, visando o controle racional da praga. Arq. Inst. Biol., vol. 32, no. 1 , p. 9-22.

RAGA, A., PRESTES, DAO., SOUZA-FILHO, MF., SATO, ME., SILOTO, RC., GUIMARÃES, JA. and ZUCCHI, RA., 2004. Fruit fly (Diptera: Tephritoidea) infestation in citrus in the State of São Paulo, Brazil. Neotrop. Entomol. vol. 33, no. 1, p. $85-89$.

SALLES, LAB., 1995. Bioecologia e controle da mosca-dasfrutas sul-americana. Pelotas: EMBRAPA, CNPCT. 58 p.

-, 1998, Principais pragas e seu controle. In: MEDEIROS, CAB. and RASEIRA, MCB. (Eds.). A cultura do pessegueiro. Brasília; Pelotas: Embrapa, SPI; Embrapa, CPACT. 350 p.

SANTOS, WS., CARVALHO, CAL. and MARQUES, OM., 2004. Registro de Neosilba zadolicha McAlpine \& Steyskal (Diptera: Lonchaeidae) em umbu-cajá (Anacardiaceae). Neotrop. Entomol., vol. 33, no. 5, p. 653-654.

SELIVON, D., PERONDINI, ALP., MORGANTE, JS., 2005. A genetic-morphological characterization of two cryptic species of the Anastrepha fraterculus complex (Diptera: Tephritidae). Ann. Entomol. Soc. Am., vol. 98, no. 3, p. 367-381.

SILVA, NM., SILVEIRA-NETO, S. and ZUCCHI, RA., 1996. The natural host plants of State of Amazonas, Brazil. In MCPHERON, BA. and STECK, GJ. (Eds.). Fruit fly pests: a word assessment of their biology and management. Delray Beach: Lucie Press. 596 p.

SOUZA, SAS., RESENDE, ALS., STRIKIS, PC., COSTA, JR., RICCI, MSF. and AGUIAR-MENEZES, EL., 2005. Infestação natural de moscas frugívoras (Diptera: Tephritoidea) em café arábica, sob cultivo orgânico arborizado e a pleno sol, em Valença, RJ. Neotrop. Entomol., vol. 34, no. 4, p. 639-648.

SOUZA-FILHO, MF., 1999. Biodiversidade de moscas-dasfrutas (Diptera: Tephritidae) e seus parasitóides (Hymenoptera) em plantas hospedeiras no Estado de São Paulo. Piracicaba: ESALQ/USP, 173 p. [Dissertação de Mestrado].

SOUZA-FILHO, MF., RAGA, A. and ZUCCHI, RA., 2000. São Paulo. In MALAVASI, A. and ZUCCHI, RA. (Eds.). Moscas-das-frutas de importância econômica no Brasil: conhecimento básico e aplicado. Ribeirão Preto: Holos Editora. $327 \mathrm{p}$.

SOUZA-FILHO, MF., RAGA, A., SATO, ME. and ZUCCHI, RA., 2002. Infestation of Dasiops friesenii Norrbom \& McAlpine (Diptera: Lonchaeidae) in passion fruit (Passiflora edulis f. flavicarpa). In Congresso Brasileiro de Entomologia, junho, 2002. Manaus: SEB, 2002.

STRIKIS, PC. and SOUZA-FILHO, MF., 2004. Comportamento de cópula de Neosilba glaberrima e $N$. zadolicha (Diptera: Lonchaeidae) em condição natural. In Congresso Brasileiro de Entomologia, setembro, 2004. Gramado: SEB, 2004.

UCHÔA-FERNANDES, MA., OLIVEIRA, I., MOLINA, RMS. and ZUCCHI, RA., 2002. Species diversity of frugivorous flies (Diptera: Tephritidae) from hosts in the cerrado of the State of Mato Grosso do Sul, Brazil. Neotrop. Entomol., vol. 31, no. 4, p. $515-524$

UCHÔA-FERNANDES, MA., OLIVEIRA, I., MOLINA, RMS. and ZUCCHI, RA., 2003. Biodiversity of frugivorous flies (Diptera: Tephritoidea) captured in citrus groves, Mato Grosso do Sul, Brazil. Neotrop. Entomol., vol. 32, no. 2, p. 239-246.

VELOSO, VRS., 1997. Dinâmica populacional de Anastrepha spp. e Ceratitis capitata (Wied 1824) (Diptera, Tephritidae) nos cerrados de Goiás. Goiânia: Escola de Agronomia/UFG. 115 p. [Tese de Doutorado].

ZUCCHI, RA., 2000. Taxonomia. In MALAVASI, A. and ZUCCHI, RA. (Eds.). Moscas-das-frutas de importância econômica no Brasil: conhecimento básico e aplicado. Ribeirão Preto: Holos Editora. 327 p. 